\title{
Combining sediment Cladocera remains and geochemistry to reveal the role of a large catchment in driving changes in a small subalpine lake (Lake Ledro, N-Italy)
}

\author{
Manuela Milan, ${ }^{1 *}$ Richard Bindler, ${ }^{1}$ Monica Tolotti ${ }^{2}$ \\ ${ }^{1}$ Department of Ecology and Environmental Sciences, Umeå University, Linnaeus väg 6, 90187 Umeå, Sweden \\ ${ }^{2}$ Sustainable ecosystems and bioresources, Research and Innovation Centre, Fondazione E. Mach, Via E. Mach 1, 38010 San Michele \\ all'Adige (TN), Italy \\ *Corresponding author: milan.manuela@gmail.com
}

\begin{abstract}
Sediment Cladocera remains and geochemistry were analyzed at Lake Ledro, a small subalpine lake with a large catchment area located in northern Italy. The aim of the study was to investigate human, climate and hydrological impacts on the Cladocera community and on the geochemical components during the last few centuries. A sediment core was collected from the deepest point of Lake Ledro and radiometrically dated. Cladocera remains were analyzed to track the trophic lake evolution. The core bottom section revealed the dominance of Bosminidae in concomitance with nutrient pulses entering into the lake during major flood events. The abundance of species preferring cold water temperatures confirmed the deposition of this core section during the Little Ice Age. The flood event occurred in the first half of the $19^{\text {th }}$ century produced a drastic increase in littoral species, due to the development of new habitats. The decrease in Cladocera densities during the following lake stage was followed by a rapid increase in planktonic species during the nutrient enrichment after the 1960s. Statistical analyses revealed a clear response of Cladocera community to climate variability during oligotrophic periods, while no relation to temperature changes was recorded during high nutrient levels. A preliminary study on Bosminidae and Daphnidae body size and appendages length was carried out to reconstruct major changes in the lake food web. Only Bosmina spp. revealed clear body size changes: minor shifts were recorded before the 1930s in relation to the low nutrient concentrations, while the major changes occurred during the 1980 s were interpreted as related to the appearance of Cladocera invertebrate predators. Geochemical components were studied using X-ray fluorescence spectroscopy (XRF) analysis in order to recognize the impact of the large catchment area and from the lake-level regulations on the lake hydrology. Moreover the Si:Al ratios profile confirmed the increase in lake productivity after the 1960s. Although both Cladocera and geochemical analysis indicate major changes since the 1960s, they also revealed diverse responses to common external and local forcing, thus confirming the value of a multi-proxy approach for disentangling the lake responses to different environmental stressors. Moreover, it outlined the importance of larger catchment areas on small lakes as they are to a larger extent influenced by the modifications occurring in the drainage basin.
\end{abstract}

Key words: Cladocera; geochemistry; wavelenght-dispersive X-ray fluorescence spectroscopy; paleolimnology; hydrological impact; Bosmina morphology.

Received: November 2016. Accepted: December 2016.

\section{INTRODUCTION}

The application of the multiproxy approach in paleolimnological studies is becoming increasingly widespread as it allows to integrate the responses of lakes and their catchment and to disentangle the effects of combined human and climate impacts (Batterbee, 2000; Bennion et al., 2015). The combination of biological and geochemical proxies allows tracking different aspects of specific impacts (Bennion et al., 2015; Perga et al., 2015), and overtaking the limits of the different studied proxies, such as Cladocera, diatoms, subfossil pigments and lithogenic elements (Rosen et al., 2010).

Cladocera represent key players of the lake food web as they act between top-down regulators (fish and invertebrate predators) and bottom-up factors (nutrients and phytoplankton; Eggermont and Martens, 2011). In particular, the study of Cladocera remains allows to reconstruct changes in lake trophic status (Jeppesen et al., 2001), water temperature (Nevalainen, 2012; Szeroczyńska, 2006) and pH (Jeziorski et al., 2008), water level (Korhola et al., 2005), macrophyte distribution (Davidson et al., 2007), and food web (Finney et al., 2000; Jeppesen et al., 2001). The studies by Manca et al. (2007) and Korosi et al. (2010) on changes in Cladocera body and appendages length over longer periods highlighted that size varies in relation to predators pressures, water temperature, nutrient, $\mathrm{pH}$ and $\mathrm{Ca}$. These analyses resulted to be particularly useful when long-term data on fish and invertebrate predators are not available, as well as to support information provided by other proxies.

Geochemical analyses of lake sediments have been 
successfully used to reveal responses of lake ecosystems to catchment change (Battarbee, 2000). In fact, soil stabilization and erosion are strongly influenced by land-use (García-Ruiz et al. 2010), while physical and chemical weathering of the catchment area are affected by climatic variability (Vannière et al., 2013). The analysis of different geochemical components can provide information on lake productivity (e.g., Si:Al as a proxy of biogenic silica), redox conditions (i.e., Fe:Mn ratios), atmospheric pollution (e.g., $\mathrm{Pb}$ concentration), land use (lithogenic elements), climate change and weathering rates ( $\mathrm{K}: \mathrm{Al}$ ratios; Martín-Puertas et al., 2011).

Several paleolimnological studies were conducted on subalpine lakes located on the northern slope of the Alps (Alefs and Müller, 1999, Berthon et al., 2013; Wessels et al., 1999), while only a few sediment records were studied on the southern side (Marchetto et al., 2004; Guilizzoni et al., 2006; Milan et al., 2015). As already anticipated by Battarbee (2000), the recent work on the largest Italian lake, Lake Garda (Milan et al., 2015), highlighted the necessity to expand the study to other lakes of the Italian subalpine region in order to understand both the individualistic response to common external forcing, and the importance of local factors in driving the lake dynamics at secular scale. Lake Ledro appeared to be the ideal site to begin this expansion as it is located very close to Lake Garda and its large drainage basin has a great influence on the lake hydrology. Several physical analyses were recently conducted on the sediments of this lake in order to understand the impact of flood events on the lake (Magny et al., 2012; Vannière et al., 2013; Simonneau et al., 2013b). However, the response of the biological communities to long term changes is still unknown as sediments of Lake Ledro were never analyzed for biological proxies.

The aim of this work was to reconstruct the long-term influence of human, climate and hydrological impacts on biological and geochemical components of Lake Ledro during the last few centuries. The multiproxy approach was applied in order to identify and disentangle the effects of the different impacts on the lake-catchment systems. This appears to be of particularly importance for this lake as its large drainage basin is related to major source of disturbance. Cladocera remains were identified in the sediment samples and related with independent environmental and climatic variables in order to reconstruct the influence on the lake biological community exerted by major climate changes as occurred for example during the Little Ice Age, by the post-war nutrient enrichment and by major flood events.

A preliminary study on the body size and appendages length was carried out in order to overtake the lack of long-term predator information. Finally, sediment samples were analyzed by X-ray fluorescence spectroscopy (XRF) for the reconstruction of the geochemical changes. The different elements and ratios have been compared in order to understand magnitude and impacts on the lake dynamics of major flood events and water-level regulations.

\section{METHODS}

\section{Study site}

Lake Ledro is a small glacial lake (area: $3.7 \mathrm{~km}^{2}$, Vol: $0.08 \mathrm{~km}^{3}, \mathrm{Z}_{\max }: 49 \mathrm{~m}$ ) with a catchment area of ca. 111 $\mathrm{km}^{2}$, ranging from $2254 \mathrm{~m}$ asl down to $652 \mathrm{~m}$ asl (Fig. 1). Several stages of high flood frequency during the Holocene were outlined by previous studies on Lake Ledro sediments and interpreted in relation to combined effects of the torrential regime of the two temporary tributaries, Massangla and Pur rivers, the steepness of their valleys and the high ratio between catchment and lake area (30:1 ratio, Vannière et al., 2013; Simonneau et al., 2013b).

Lake Ledro is situated very close to the northern extremity of Lake Garda (Fig. 1), the largest Italian lake, to which it is connected through an underwater pipe located at $25 \mathrm{~m}$ depth in Lake Ledro. Water is forced through a pump-storage power plant built on the River Ponale down to Lake Garda, and then the water is pumped back up. The lake-level of Lake Ledro has been regulated for hydroelectricity production since AD 1929 (Vannière et al., 2013).

\section{Sediment coring and chronology}

A gravity corer (UWITEC, Austria) was used to collect a short core $(83 \mathrm{~cm})$ from the deepest point of Lake Ledro (45 52'44'N, 1045'10'E) in December 2011. The core was vertically extruded and sliced in the laboratory at $0.5 \mathrm{~cm}$ intervals from 0 to $30 \mathrm{~cm}$, and at $1 \mathrm{~cm}$ intervals from $31 \mathrm{~cm}$ down to the core bottom. Sediment aspect and texture were annotated during the slicing. The core chronology was established applying the CRS dating model (Appleby, 2001) to direct gamma assay radiometric analyses of ${ }^{210} \mathrm{~Pb},{ }^{226} \mathrm{Ra},{ }^{137} \mathrm{Cs}$ and ${ }^{241} \mathrm{Am}$, which were conducted at ENSIS Ltd-University College London, UK.

\section{Geochemistry and subfossil pigments}

Wet density (WD), water content $\left(\mathrm{H}_{2} \mathrm{O}\right.$, measured from dry weight) and total organic matter $(\mathrm{OM}$, measured as loss on ignition at $550^{\circ} \mathrm{C}$ ) were determined for all the subsamples as described in Milan et al. (2015). About 0.2 $\mathrm{g}$ of dried and homogenized sediment were used to measure major and trace elements using a Bruker S8 Tiger WD-XRF analyzer equipped with an Rh anticathode Xray tube (further detail in Rydberg, 2014). The analysis showed accuracy within $10 \%$ and analytical precision within $5 \%$ for the majority of the elements. Concentrations of key groups (i.e., major elements, redox, litholog- 
ical and trace elements) and ratios between specific elements are discussed in this study. In particular, the $\mathrm{Mn}: \mathrm{Fe}$ ratio was used to infer changes in the sediment redox conditions, while the $\mathrm{Si}: \mathrm{Al}$ ratio was used to infer changes in biogenic silica. The $\mathrm{Pb}$ enrichment factor (PbEF) was calculated in order to outline the atmospheric pollution in this region by using titanium (Ti) as the reference element. The value of $\mathrm{Pb}$ :Ti ratio in the deepest sediment layers was used as reference. The $\mathrm{Zr}$ :Ti ratio indicated the changes in grain size patterns and was used to understand the possible impacts of secular changes of hydrological dynamics the on the sediment quality (Boyle, 2000). The ratio $\mathrm{K}: \mathrm{Al}$ was considered to identify mineral matter changes, since lower values generally reflect more-weathered mineral matter and viceversa (Kauppila and Salonen, 1997). All the stratigraphic plots were drawn with the software C2 version 1.7.2 (Juggins, 2007).

Around $0.5 \mathrm{~g}$ of wet sediment of each subsample were extracted in $90 \%$ acetone overnight in the dark and under nitrogen atmosphere for photosynthetic pigments analysis, which were carried out at CNR-ISE (Verbania, Italy). After centrifugation (3000 rpm, $10 \mathrm{~min}$ ) the sediment was removed and the obtained extract was used to quantify total carotenoids (TCar) by double beam spectrophotometer (SAFAS, UVmc2), and astaxanthin (Asta) by Reversed Phase High-Performance Liquid Chromatography using a Thermo Separation HPLC (Ultimate 3000). TCar was used to infer past total phosphorus concentration (Car-TP) according to Guilizzoni et al. (2011).

\section{Subfossil Cladocera}

Cladocera remains were analyzed every fourth sample along the core following the methods described by Szeroczyńska and Sarmaja-Korjonen (2007). About $2 \mathrm{~cm}^{3}$ of wet sediment were treated with $\mathrm{KOH}(10 \%)$ and $\mathrm{HCl}$ $(10 \%)$. Asafranin-glicerol mixture was added to the cleaned subsamples of $0.1 \mathrm{ml}$ in order to facilitate the identification of the remains under an optical microscope (LEICA DM2500) at 100-400x magnification. All Cladocera remains (headshield, shell, postabdomen, postabdominal claws, mandible, caudal furca) were counted, and converted to number of individuals following Frey (1986). Taxonomical identification was based on Flössner (2000), Margaritora (1983) and Szeroczyńska and Sarmaja-Korjonen (2007). Three to six slides were counted for each sample in order to obtain a minimum of 100 Cladocera individuals (Kurek et al., 2010). This minimum was not achieved in a few samples with extremely scarce Cladocera remains. In order to preliminary explore the influence of environmental variables on Cladocera body size changes, ca. 30 carapace, mucro and antennules of different Bosminidae species and 30 postabdominal claws of Daphnidae were measured in each sample (Korosi et al., 2008).

\section{Environmental variables and data analysis}

Homogenized monthly average air temperature data for the period 1870-2008 were obtained from the HISTALP webpage (2013) for the station Torbole-Riva del Garda, which is located at $5 \mathrm{~km}$ away from Lake Ledro. In this work only annual and seasonal average air temperature were considered, as previous statistical analyses (Milan, 2016) showed no relation between precipitation data and Cladocera. Information on lake nutrients and plankton were collected from the literature (Casellato, 1990; Boscaini et al., 2012) and from the Environmental Agency of the Autonomous Province of Trento (unpublished data).

Past lake total phosphorus concentrations were inferred from both concentrations of total carotenoids (TCar, see above) and subfossil diatoms. Diatom-inferred total phosphorus concentrations (DITP) were reconstructed basing on a weighted-average regressions (WA) with inverse deshrinking, calibrated against the NW-European datasets (NW-Eu, Bennion et al., 1996). Further details on diatoms and pigment composition as well as TP reconstruction are available in Milan (2016).

The optimal partitioning method based on the sum of squares criterion and implemented in the ZONE software (Lotter and Juggins, 1991) was used to identify the homogenous Cladocera zones along the master core, while the number of significant zones was established through comparison with the broken stick model (Bennett, 1996). The binary logarithm-based Shannon Index (Shannon and Weaver, 1949) was applied to determine the diversity of

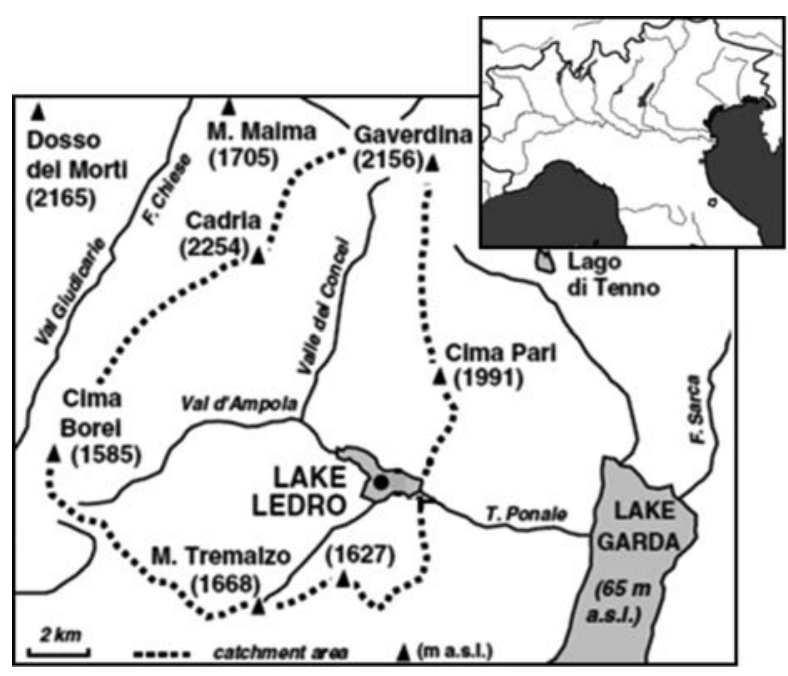

Fig. 1. Study site including catchment area for Lake Ledro. Dot indicates the coring point. 
Cladocera assemblages. The ratio of planktonic to littoral taxa was calculated for every analysed subsample, since planktonic species are expected to be dominant under warmer conditions and/or water level increase (SarmajaKorjonen, 2001). Bosmina longirostris (O.F. Müller) was excluded from this classification due to its capacity to live in both the pelagic and littoral zones (Szeroczyńska, 1998). Specific ecological preferences were defined as in Korhola (1990), Frey (1986) and Margaritora (1983).

In order to identify patterns in the temporal evolution of Cladocera assemblages, a non-metric multidimensional scaling (NMDS, Kruskal and Wish, 1978) was applied to a Bray \& Curtis dissimilarity matrix computed on the square root of Cladocera abundances. The NMDS analysis was performed with R 3.3.1 (R Core Team, 2016), vegan package version 2.4-1 (Oksanen et al., 2016), and after 20 trials the NMDS solution providing the lowest 'stress' (i.e. 0.16), which is measure of the configuration stability (Legendre and Legendre, 1998), was selected. A scree plot analysis was performed in order to determine the final number of NMDS dimensions to be considered (Legendre and Legendre, loc. cit.).

For the identification of the major environmental, climatic and geochemical drivers for the studied proxy, vector and surface fitting analyses were applied respectively to the sample scores of the NMDS configurations. Only variables significantly $(\mathrm{P}<0.05)$ correlated to sample score were considered in this work and plotted in the graph. The two analyses were computed using R 3.3.1 (R Core Team, 2016), vegan package version 2.4-1 (Oksanen et al., 2016).

A LOWESS interpolation of the non-contiguous radioisotopic ages was performed (R 3.3.1; R Core Team, loc. cit.) in order to attribute ages and sedimentation rates to each subsample within the ${ }^{210} \mathrm{~Pb}$ dated core section. A Kruskal-Wallis test was applied as non-parametric test for non-normal distributed variables to sediments sections characterized by homogeneous Clacodera body size, in order to verify the significance of different average sizes (Kruskal and Wallis, 1952). PAST software was used for the statistical analysis on the Clacodera body measurements (Hammer et al., 2010).

\section{RESULTS}

\section{Core chronology}

${ }^{210} \mathrm{~Pb}$ equilibrium was reached in the core of Lake Ledro at $28 \mathrm{~cm}$ depth, while ${ }^{137} \mathrm{Cs}$ showed a well resolved peak at 21.25 (coincident with a peak in ${ }^{241} \mathrm{Am}$ ) and a minor one at $10.25 \mathrm{~cm}$, corresponding to the fallout from atmospheric testing of nuclear weapons in 1963 and from the Chernobyl accident in 1986, respectively. The chronologies and the sediment accumulation rates were calculated by the CRS model using the ${ }^{137} \mathrm{Cs}$ peak at $21.25 \mathrm{~cm}$ as reference level for 1963 . The sediment accumulation rates (Fig. 2) showed a gradual increase in the last hundred years and a peak in the middle 1960s, which could be the result of either a sediment slumping or of the "century" flood event, which interested the north and central Italy in November 1966 (Malguzzi et al., 2006). The core showed major discontinuities at 40,51, 59, 68 and $78 \mathrm{~cm}$ depth, which were interpreted as flood events by comparison with the structure of the core collected at 46 $\mathrm{m}$ depth in 2008 by Simonneau et al. (2013b). Other minor discontinuities detected in the core top $30 \mathrm{~cm}$ were related to minor floods (e.g., 1966) or to particularly rainy years (e.g., 1996, 2002, 2007).

\section{Geochemistry and subfossil pigments}

Wet density values oscillated in the core studied between 1.3 and $1.6 \mathrm{~g} \mathrm{~cm}^{-3}$. The highest values recorded be-

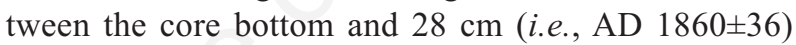
indicated high proportion of mineral matter during the Little Ice Age (Fig. 2). The upper $28 \mathrm{~cm}$ were characterized by gradually decreasing sediment densities with two peaks, one in the 1990s and one in the 2000s. Water content oscillated around $\sim 50 \%$ of fresh weight (FW) from the core bottom to $55 \mathrm{~cm}$ depth, and increased thereafter up to $>80 \%$ in the upper $5 \mathrm{~cm}$ (Fig. 2). Organic content slightly decreased from core bottom to $28 \mathrm{~cm}$ depth (from $14 \%$ to $8 \%$ of DW), while it irregularly increased in the upper core section and reached maximum values in the early 1970s (at $\sim 18 \mathrm{~cm}$ ) and in the second half of the 2000s (at $\sim 3$ cm; Fig. 2).

The depth profile of astaxanthin (a marker for N-limited cyanobacteria and aquatic invertebrates, including zooplankton) oscillated between $\sim 2$ and $30 \mathrm{nmol} \mathrm{g}^{-1}$ LOI throughout the core (Fig. 2). Total carotenoid concentration were low in the deeper core sections, while they increased up to $3.4 \mathrm{U} \mathrm{g}^{-1}$ LOI during the $1980 \mathrm{~s}$ and to $\sim 4 \mathrm{U} \mathrm{g}^{-1} \mathrm{LOI}$ in the early 2000 s (Fig. 2). The past lake TP inferred on total carotenoid concentration (Car-TP, Fig. 2) oscillated between 5 and $8 \mu \mathrm{g} \mathrm{L}^{-1}$ from the core bottom up to $\sim 20 \mathrm{~cm}$ depth (late 1960s), while the upper section showed two rapid increases up to mesotrophic level $\left(>25 \mu \mathrm{g} \mathrm{L}^{-1}\right)$, the first one in the 1970-1980s and the second one between the late 1990s to the beginning of the 2000s. These two maxima were separated by a sharp drop down to base line TP values in the 1990s (Fig. 2). Sediment surface Car-TP concentrations (10-15 $\left.\mu \mathrm{g} \mathrm{L}^{-1}\right)$ agreed with present mesotrophic status of Lake Ledro.

The Car-TP pattern at Lake Ledro was highly comparable to the TP profile inferred from subfossil diatoms (DI-TP, Fig. 2). However, DI-TP concentrations reached in general higher values than Car-TP and showed enhanced values also around $30 \mathrm{~cm}$ depth (i.e., during the middle $19^{\text {th }}$ century). DI-TP values oscillated around 10 
$\mu \mathrm{g} \mathrm{L} \mathrm{L}^{-1}$ from the bottom till the late $1960 \mathrm{~s}(\sim 20 \mathrm{~cm}$ depth), when they started to increase up to maximum values around $70 \mu \mathrm{g} \mathrm{L}^{-1}$ in the second half of the $1970 \mathrm{~s}$ and the end of the 1980s, and to values of $\sim 78 \mu \mathrm{g} \mathrm{L}-1$ in the second half of the 2000s (Fig. 2).

\section{Subfossil Cladocera}

The 33 Cladocera taxa (6 planktonic and 27 littoral), which were identified in Lake Ledro belonged to the families Leptodoridae, Daphnidae, Bosminidae, Chydoridae, Cercopagidae. Three major zones were identified based on the Cladocera assemblages and abundances (Fig. 3). The first zone (LC1, 82.5-36.5 cm depth), was mainly characterized by the presence of $B$. longirostris, which was also responsible for the high values of total Cladocera abundance (Total) in the bottom core section. Bosmina (E.) longispina Leydig and a few individuals of Chydoridae were also found in this section. The sediment layer around $38.5 \mathrm{~cm}$ depth revealed the lowest Cladocera abundance value of the entire core, and in this core section only a few individuals of $B$. (E.) longispina, B. longirostris, Acroperus harpae (Baird) and Alona affinis (Leydig) were identified. In agreement with the species scarcity of this zone, the Shannon Index showed low values around 1. A rapid increase in littoral species, especially those connected with high water turbidity, such as Alona rectangula Sars and Chydorus sphaericus (O.F. Müller), or those associated with abundant detritus, like Disparalona rostrata

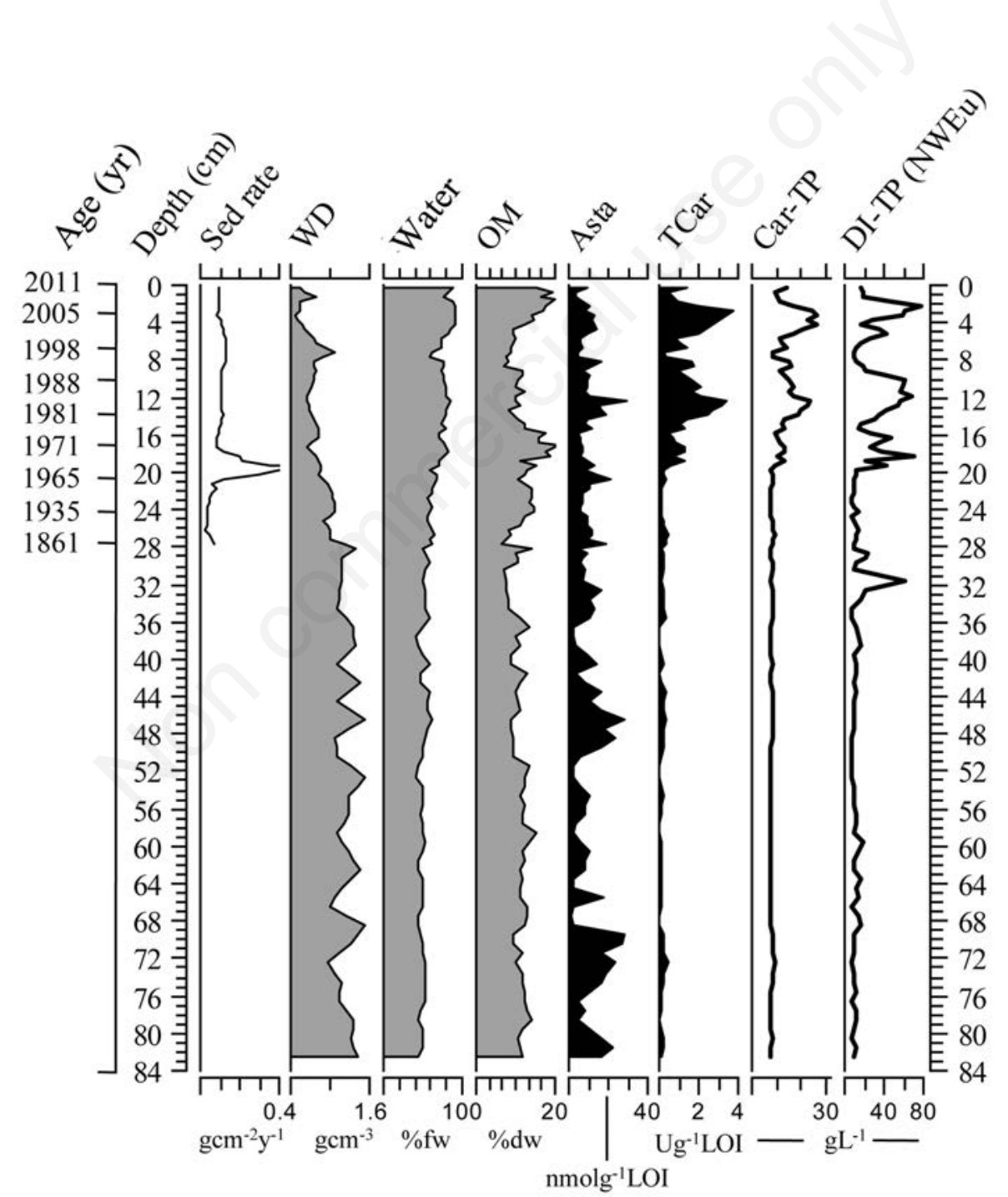

Fig. 2. Depth profiles of geochemical and biological proxies in the Lake Ledro. Sed rate, sedimentation rate; WD, wet density (x-axis from 1 to 1.6); Water, water content; OM, organic content; Asta, astaxanthin (LOI, loss on ignition); TCar, Total carotenoids concentrations; Car-TP, total phosphorus concentration reconstructed from total carotenoids levels; DI-TP, diatoms inferred total phosphorus concentrations. 
(Koch), characterized the zone LC2 (36.5-29.25 cm, Fig. 3). High abundances of $A$. harpae and $A$. affinis were also found in this zone, while $B$. longirostris and $B$. (E.) longispina showed very low density in comparison to LC1. Cladocera diversity reached the highest values of the entire in this section (Shannon Index $=3$ ).

The zone LC3 $(29.25-0.0 \mathrm{~cm})$ was characterized by an increase in density and diversity of planktonic species (Fig. 3), which were used to define the two subzones LC3a and LC3b. LC3a $(29.25-19.25 \mathrm{~cm})$ showed a rapid decrease in total Cladocera abundance, while only sporadic individuals of $B$. longirostris were identified. Daphnia longispina O.F. Müller increased gradually, and Bosmina (E.) coregoni Baird appeared for the first time in this section (i.e., after the 1930s). Compared to the previous zone, the Shannon Index decreased in association to the abundance of planktonic species. The dominance of planktonic and the sporadic presence of littoral species marked zone LC3b (19.25-0.0 cm). Planktonic species further increased since the early $1960 \mathrm{~s}(19.25 \mathrm{~cm})$ and culminated in the late 1980 s, when they determined the peak in total Cladocera abundance. A few individuals of
B. longirostris were identified at the beginning of LC $3 \mathrm{~b}$ subzone, while it completely disappeared in the surface layers. The cladoceran predators Bythotrephes longimanus Leydig and Leptodora kindtii (Focke) appeared for the first time in this zone and reached their maximum values at 10.25 and $12.25 \mathrm{~cm}$, respectively. Cladocera diversity showed a further regular decrease since the beginning of the subzone LC3b (Fig. 3). The highest Cladocera abundance along the core largely corresponded to stages of higher astaxanthin concentrations (Fig. 2).

Fig. 4 summarizes the results of the Cladocera measurements. No trend was observed for D. longispina (not represented in Fig. 4), while Bosminidae exhibited a major shift during the 1980s. In particular, antennulae of $B$. (E.) coregoni clearly increased after the $1960 \mathrm{~s}(\sim 20 \mathrm{~cm}$ depth), and in particularly during the 1980 s, while carapace and mucro sizes increased only since the 1980s $(\sim 10$ $\mathrm{cm}$ depth) and following a decreasing stage from the 1960 s to the 1980 s (Fig. 4). Antennules and mucro of $B$. (E.) longispina showed a relatively comparable trend, while carapace size clearly increased only after the 1980s. Despite the high abundance of $B$. longirostris especially

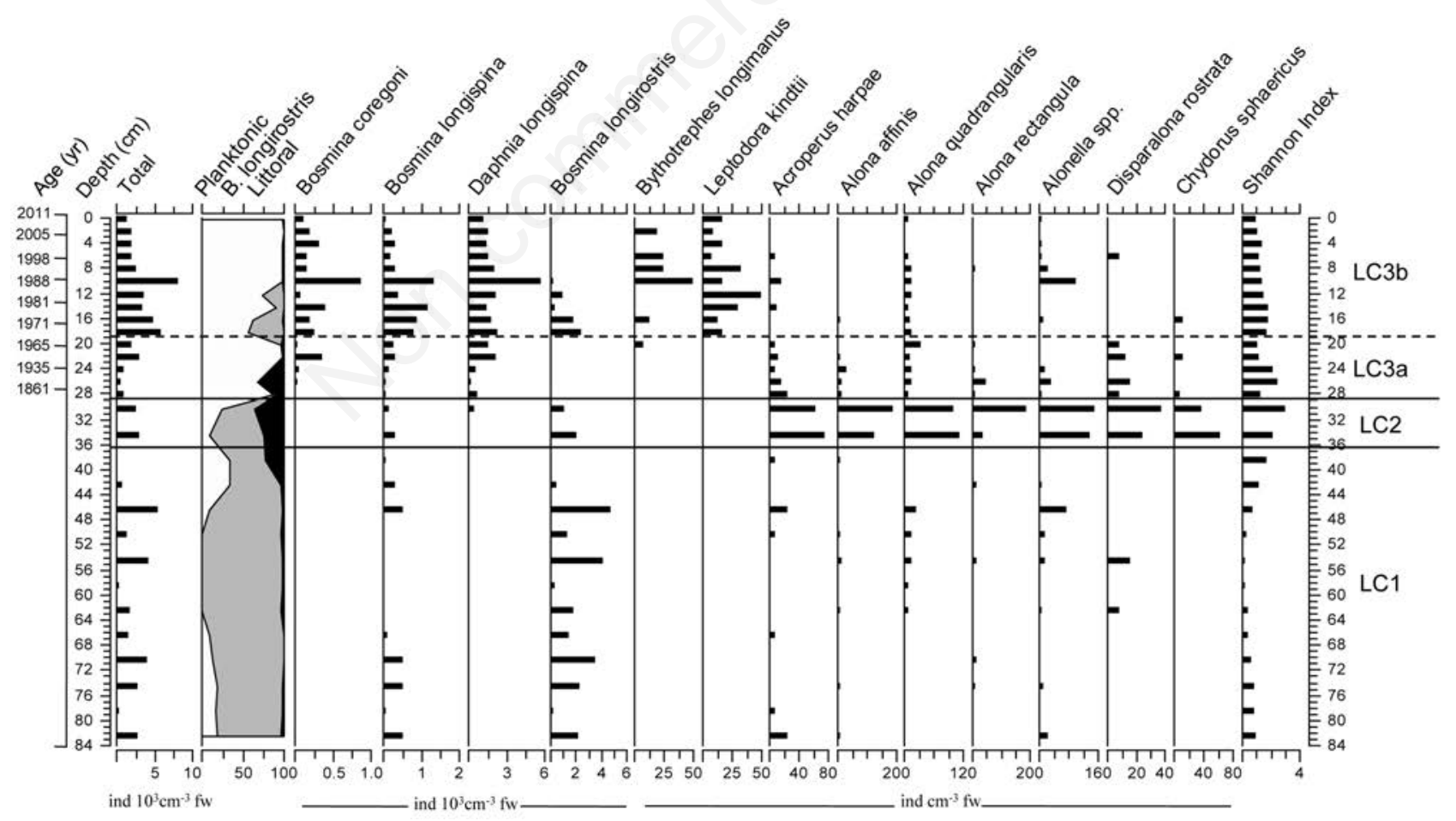

Fig. 3. Depth profiles of: subfossil Cladocera total abundance (Total); ecological classification: Planktonic (white), B. longirostris (grey), Littoral (black); key species and Shannon Index. LC1-LC3b represented the homogeneous Cladocera zones. Species codes and full names of taxa are presented in Supplementary Tab. 2. 
in the deeper core sections, the remains were often broken and the measurement of the body parts was hard.

As major changes in Bosmina body size occurred around $\sim 10 \mathrm{~cm}$ depth, average sizes above and below this level were compared through the Kruskal-Wallys test (Fig. 4, Supplementary Tab. 1). Only the mucro of $B$. longispina were analyzed for three groups, i.e. between $0-10 \mathrm{~cm}, 10-26 \mathrm{~cm}$ and $26-82 \mathrm{~cm}$. Size differences between the two core sections were significant $(\mathrm{P}<0.05)$ for antennules and mucro of B.(E.) coregoni and for antennules and carapace of $B$.(E.) longispina. While differences between the three groups were significant $(\mathrm{P}<0.001)$ for mucro of B.(E.) longispina.

\section{Environmental variables and data analyses}

The scree plot analysis indicated two dimensional NMDS as sufficient to describe the diversity of subfossil Cladocera data. The analysis revealed an evident grouping of the planktonic species in the NMDS lower left quadrant, while littoral species were concentrated in the two upper quadrants. B. longirostris, resulted to be separated from all the other species in the lower right quadrant (Fig. $5 a$ ), in agreement with its ecological characteristics (i.e., its capacity to live in both the pelagic and the littoral lake habitat). The separation of planktonic from littoral species along the first NMDS dimension (DIM1) corresponded to the species change which identified the separation of Cladocera subzones LC3a and LC3b along the core (Fig. $3)$. Moreover, the sample score on the second NMDS dimension (DIM2, not shown) highlighted a drastic change at $38.5 \mathrm{~cm}$ depth, as already outlined by the Cladocera assemblages (Fig. 3). The vector fitting outlined strong positive relations of the Cladocera assemblages with water content (Water), Tcar, Car-TP and DI-TP $(0.30<\mathrm{r}<0.69$, $\mathrm{P}<0.001$, Fig. 5b), while presented a negative correlation with WD ( $r=0.62, \mathrm{P}<0.001$, Fig. 5b). Surface fitting confirmed the strong correlation between Cladocera assemblages and DI-TP, and the relation between planktonic species and high water TP levels (Fig. 5b). The vector and the surface fitting analyses using temperature variables were limited only to the ${ }^{210} \mathrm{~Pb}$-dated core section. The vector fitting indicated only a weak correlation between Cladocera composition and the HISTALP spring temperatures (Tmm, r=0.45, P $<0.05$, Fig. $5 \mathrm{c}$ ) for the period between 1870 and 2008, while the surface fitting showed a correlation between mean annual air temperature and the recent samples (i.e., after the 1980).

\section{Geochemical records (XRF data)}

The depth profiles of the majority of the analyzed elements and ratios showed continuous oscillations, with only some elements (such as Mg and Ti; Fig. 6) showing a slight tendency to a reduction toward the sediment sur- face. $\mathrm{Mg}$ and $\mathrm{Al}$ oscillated around 2.5\%, Ca fluctuated around $21 \%$ and $\mathrm{Mn}$ around $430 \mu \mathrm{g} \mathrm{g}^{-1}$. P and P:Ti ratios exhibited stable values until $\sim 25$ and $20 \mathrm{~cm}$ depth, respectively ( $\sim 1920$ s and 1950s), while both showed a slight increase and a peak at the beginning of the 2000s. In the same period $\mathrm{Br}$ also recorded a peak. A generally declining trend was recorded for Ti until the 1940s, when it decreased from values around $1400 \mu \mathrm{g} \mathrm{g}^{-1}$ to values around $1000 \mu \mathrm{g} \mathrm{g}^{-1}$. Pb and PbEF values increased during the first half of the 1900s until the peak in the 1970s. Fluctuations were observed also in almost all the ratios (Fig. 6). Zr:Ti showed an increase in the fluctuation frequency after the 1930-1940s. A marked increase in Si:Al values after the 1970s is superimposed to the long-term steady trend of this marker. In Fig. $5 \mathrm{~d}$ the vector fitting analysis showed a strong and positive relationship of the Cladocera assemblages with different elements and ratios, i.e., $\mathrm{P}, \mathrm{Cl}, \mathrm{Br}$, Zr:TI, Si:Al, P:Ti and $\mathrm{PbEF}(0.25<\mathrm{r}<0.3 ; \mathrm{P}<0.05)$, while presented negative correlation with $\mathrm{Al}, \mathrm{K}, \mathrm{Mn}, \mathrm{Ti}$ and $\mathrm{Rb}$ $(0.24<\mathrm{r}<0.37 ; \mathrm{P}<0.05)$. Surface fitting confirmed the strong correlation between Cladocera assemblages and P:Ti, and the relation between Cladocera species and the changes in grain size (Fig. 5d).

\section{DISCUSSION}

The paleolimnological study of Lake Ledro provided a retrospective analysis of the ecological and geochemical changes occurred in the last centuries in a small subalpine lake as a consequence of both anthropogenic and climate impacts. As highlighted by the ${ }^{210} \mathrm{~Pb}$-based chronology, the core layer at $27.75 \mathrm{~cm}$ depth was deposited $150 \pm 23$ years ago. The core revealed several discontinuities in its structure, which were interpreted as flood records in relation to their aspect and enhanced wet density. The numerous flood markers in the deep section of the core investigated prevented the estimation of the core bottom age through the application of age-depths models. The arrangement of the flood records along the core and their higher frequency before the 1900s agreed with results of recent investigations focused on the hydrological history of Lake Ledro (Simonneau et al., 2013a; Vannière et al., 2013). No major discontinuities were found in the studied core after the 1900s. Nevertheless, the enhanced sedimentation rates around $20 \mathrm{~cm}$ depth was interpreted as the century flood of 1966 (Malguzzi et al., 2006), while the higher wet density and organic content registered in the surface layers could probably be identified as a result of the particularly abundant summer (as in 1996 and 2002) or winter (2004-2005, 2008-2009) precipitations (Milan, 2016). The depth profile of astaxanthin showed high concentrations along the entire core and its peak values corresponded to maximum abundance of total Cladocera 
recorded in the late 1980s. On the other hand, TCar showed very low concentrations before the 1960s, suggesting low phytoplankton densities, possibly accompanied by poor preservation of the most labile carotenoids in the oldest core sections. The depth profile of the subfossil pigment-inferred lake TP concentrations (Car-TP) reflected the TCar profile and its values were in general lower that TP concentrations inferred from sediment diatoms (DI-TP), especially in the upper core section. Both Car-TP and DI-TP showed stable oligotrophic conditions until the 1960s, and a successive increase up to maximum values during the 1980s and again at the beginning of the 2000s. However, Car-TP concentration never exceeded mesotrophic values $\left(\sim 26 \mathrm{mg} \mathrm{L}^{-1}\right)$, while DI-TP reached clearly eutrophic levels $\left(\sim 78 \mathrm{mgL}^{-1}\right)$ in the same periods. Maximum DI-TP levels agree with the lake eutrophic condition reported in the literature (Casellato, 1990; Boscaini et al., 2012). The discrepancy between TP reconstruction based on subfossil pigments and diatoms, respectively, especially for periods of higher lake productivity, has been often observed and may be related to the higher degradation rates of pigments in the sediment respect to diatoms (Guilizzoni et al., 2011). The peak DI-TP values before 1860 s were not matched by correspondent maximum in

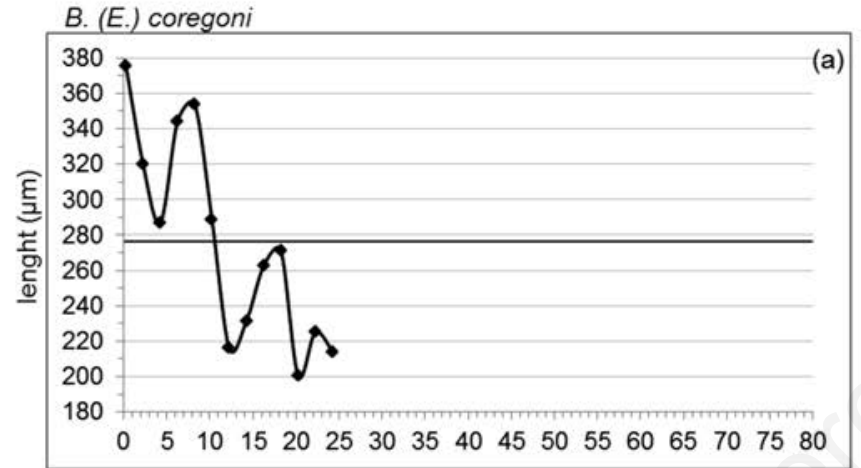

B. (E.) longispina
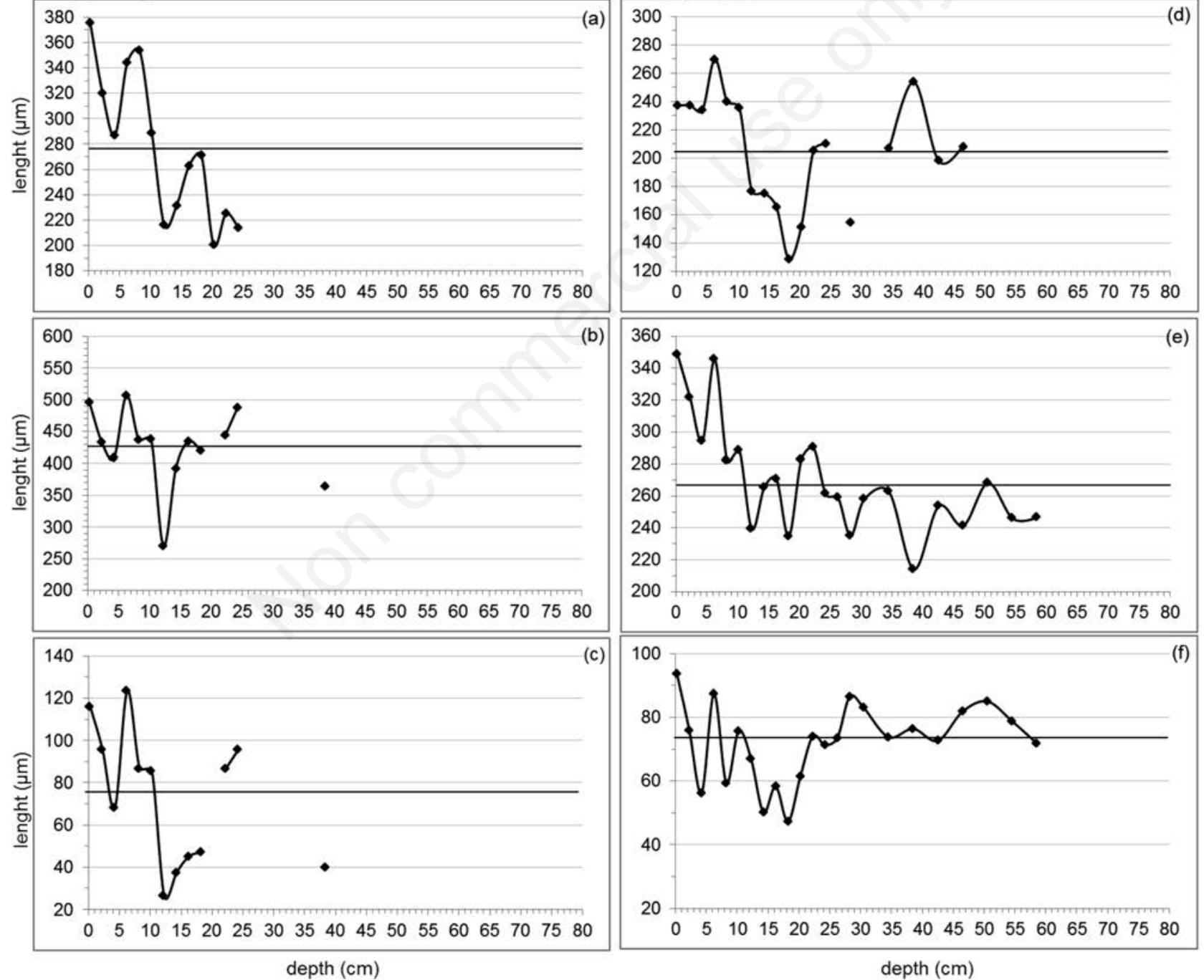

Fig. 4. B.(E.) coregoni (a-c) and B.(E.) longispina (d-f) body size measurements: antennules (a,d), carapace (b,e), mucro (c,f). The values indicate the average deviations of each sample from the general average size calculated for all the individuals measured (bold horizontal line). X-axis refers to core depths, from core surface $(0 \mathrm{~cm})$ down to core bottom $(82.5 \mathrm{~cm})$. 

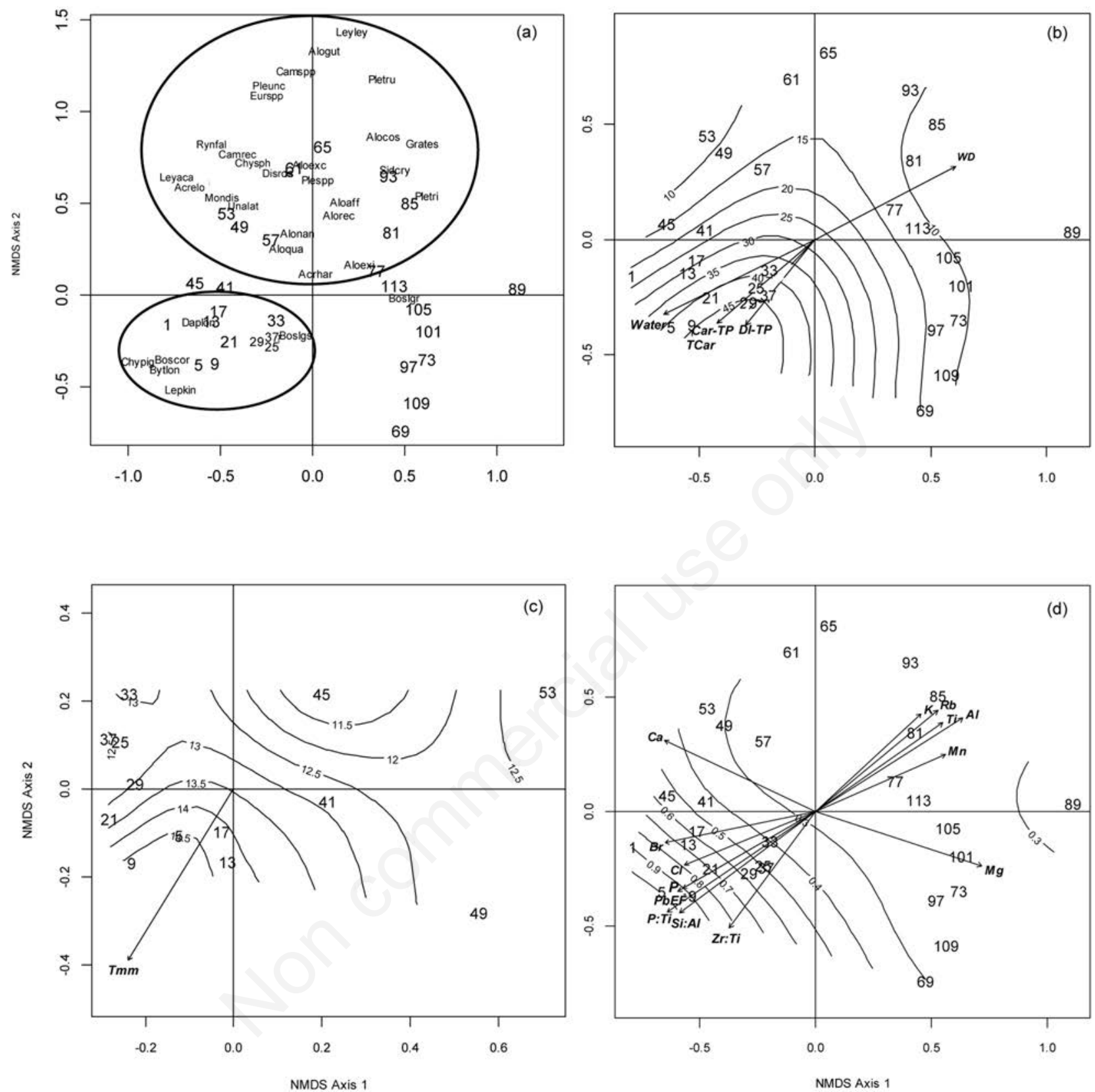

Fig. 5. Cladocera non-metric multidimensional scaling (NMDS) ordination. a) Cladocera species distributions on the samples in the ordination space; numbers in the plots refer to core samples of Lake Ledro; species codes and full names of taxa are presented in Supplementary Tab. 2. Ellipses show the major group of zooplankton species. b) Vector and surface fitting for environmental variables; the orientations of the vectors show the change direction for each environmental variable and the length indicate the correlation between the environmental variable and the sample ordination; in the plot are shown only the results that exhibited significant $(\mathrm{P}<0.05)$ correlations; WD, wet density; Water:, water content; OM, organic content; Asta, astaxanthin; TCar, total carotenoids concentrations; CarTP, total phosphorus concentration reconstructed from total carotenoids levels; DI-TP, diatoms inferred total phosphorus concentrations; the surface fitting is based on correlations with DI-TP, and the numbers on the surface lines represent the DI-TP values. c) Vector and surface fitting for climate variables. Only $\mathrm{T}_{\mathrm{mm}}$ (spring air temperature from March to May) exhibited a significant correlation with $\mathrm{P}<0.05$; the surface fitting is based on correlations with the mean annual air temperature and the numbers on the surface lines are measured mean annual air temperatures. d) Vector and surface fitting for geochemical variables based on XRF analysis. In the plot are shown only the results that exhibited significant $(\mathrm{P}<0.05)$ correlations; $\mathrm{PdEF}, \mathrm{Pb}$ enrichment factors; the surface fitting is based on correlations with the P:Ti and the numbers on the surface lines are measured P:Ti ratio. 
Car-TP. This discrepancy, which was due to a stage of very low abundances of planktonic diatoms and a high share of meso-to eutraphentic benthic diatoms, was interpreted as an effect of inorganic and organic materials dragged from the catchment into the lake by a major flood event occurred in the first half of 1800 (Milan, 2016). This may have induced a persistent increase in water turbidity and the consequent depression of phytoplankton productivity. The presence of Cladocera species preferring turbid waters, such as A. rectangula and $C$. spahericus supported the hypothesis of low water transparency (Margaritora, 1983), while the presence of $B$. longirostris during and after this flood confirmed the increased in nutrient concentrations (Boucherle and Züllig, 1983).

The Car-TP and DI-TP increase after the 1960 and their maximum values during the 1980 s corresponded to the general trophic evolution observed in other Alpine lakes in relation to the post-war economic development (Berthon et al., 2013; Milan et al., 2015). The TP pulse during the 1980s was confirmed by the limnological data collected from the Autonomus Province of Trento (unpublished data). The peak at the beginning of the 2000s was also recorded in other Alpine lakes (Milan et al., 2015; Berthon et al., 2013; Tolotti et al., 2012) and could be related to the particular weather conditions, especially to the high summer temperatures and the high snow precipitations, registered during the first half of the 2000s. In fact, Simonneau et al. (2013b) demonstrated that snow thaw is particularly efficient in dragging the nutrients stored in the lake catchment down to the lake ecosystems. Although Cladocera communities were not always well preserved in the sediments of Lake Ledro, especially during the flood events, both littoral and planktonic taxa were well represented in the core studied. The deeper section, which was supposed to cover the Little Ice Age (LIA), was characterized by an unexpected high abundance of total Cladocera as a consequence of high densities of $B$. longirostris and B.(E.) longispina. Usually, the presence of Bosminidae, and in particular of $B$. longirostris, indicate high levels of lake nutrient concentrations (Hofmann, 1998; Korosi et al., 2013), which contrasts with the information provided by the TP reconstruction based on subfossil pigments and diatoms. However, the higher density of $B$. longirostris is not in contrast with the higher hydro-

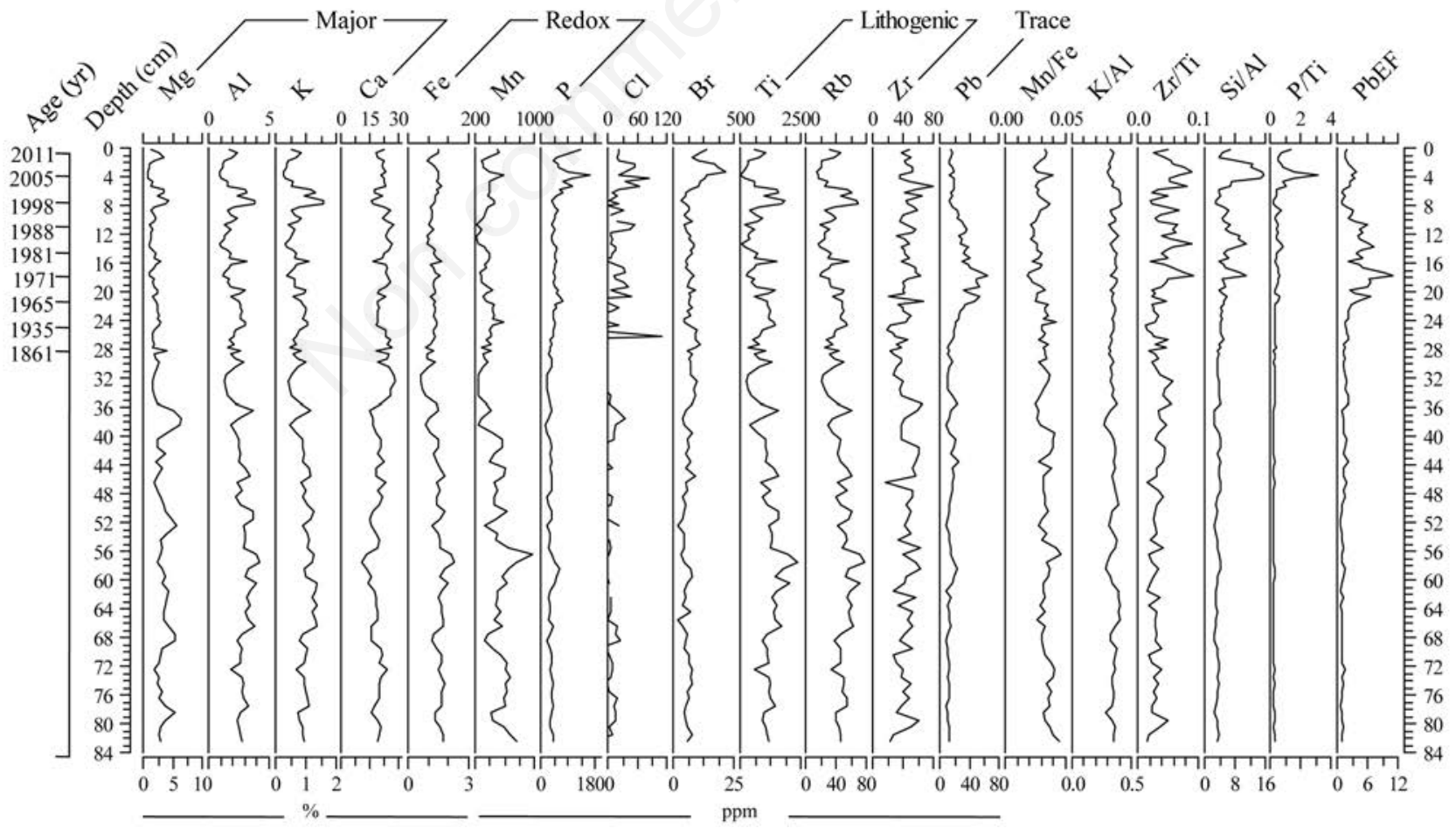

Fig. 6. Selected geochemical depth profiles. Geochemical elements are divided in major groups: Major, Redox, Lithogenic and Trace. $\mathrm{PbEF}, \mathrm{Pb}$ enrichment factors. 
logical variability of the pre- 1860 period and could be related to higher amount of particulate material and nutrients entering into the lake from the catchment area during flood events (Manca et al., 2007). On the other hand, the presence of A. harpae and A. affinis in the core bottom confirmed the deposition of these sediment layers during the LIA, as these two species were considered as early immigrants after ice retreat (Kamenik et al. 2007) and are classified as "arctic" and "sub-arctic" species, respectively (Harmsworth, 1968). In addition, $A$. harpae and $A$. affinis were the sole species identified at $38.5 \mathrm{~cm}$ depth (ca. in the early 1800s), which reinforces the hypothesis that this sediment section was deposited during the coldest period recorded in the Alpine region (De Jong et al. 2013). The lowest total Cladocera abundance and the particular species composition recorded in this layer agreed also with what observed in Lake Garda at the beginning of the 1800s. In particular, the core collected from the deepest lake basin showed the lowest Cladocera density and exclusive the presence of the $A$. harpae during this particularly cold period (Milan, 2016).

Cladocera community changed completely its species composition and reached its highest richness during the first half of the 1800 (zone LC2), which was interested by one of the biggest flood event in the whole record. Bosminidae were substituted by species preferring turbid waters, such as $A$. rectangula and C. sphaericus, and/or associate with detritus or sand, such as D. rostrata and Monospilus dispar (Sars). The presence of Campotercus rectirostris Schödler and Pleuroxus spp. (Baird), not showed in Fig. 3, suggested also an increase in mean water temperatures. The decrease in littoral species and the disappearance of B. longirostris in zone LC3a suggested a lake recovery to pre-flood event status and low TP concentrations. The decrease in nutrient was confirmed by the DI-TP, which showed a return down to oligotrophic levels after the flood. The dominance of B.(E.) longispina, $D$. longispina and $B$. longirostris since the 1960s indicated a nutrient enrichment stage (Boucherle and Züllig, 1983), in agreement with the independent pigment- and diatom-inferred TP. The planktonic species reached their highest density during the 1980 s, i.e. in concomitance with the maximum Car-TP and DI-TP values. The TP peak of 2005 and the following decrease in nutrients, did not correspond to evident changes in Cladocera assemblages, probably in relation to resuspension of Cladocera remains in uppermost core layers (Szeroczyńska, personal communication).

The multivariate statistical analyses outlined that secular changes in Cladocera communities of Lake Ledro responded weakly to mean air temperature changes, while the response to hydrological events, especially to the major flood occurred in the mid-1800s, appeared more pronounced. On the contrary, lake nutrient levels emerged as the principal Cladocera driver after the 1960s. In fact significant correlations were found between Cladocera species (in particular those identified in the upper layers) and lake nutrient level, as well as geochemical elements and ratios, while correlations with temperature variables were scarce. The highly comparable gradients of environmental, climate and geochemical variables in the vector and surface fitting analyses suggested a simultaneous and overlapped role of all the three variable groups considered in the present study in driving changes in the Cladocera assemblage. This strongly hinders the discrimination and isolation of effects by single variables.

On the other hand, this study confirmed the response of Cladocera assemblages to extreme events, which were able to induce major habitat changes, as similarly emerged from the paleolimnological study of Lake Garda (Milan, 2016).

Since Cladocera occupy an intermediate level between top-down regulators (fish and invertebrate predators) and bottom-up factors (nutrient and phytoplankton, Jeppesen et al., 2001; Szeroczyńska, 2006), the role of predation pressure should also be considered when evaluating long term changes in the Cladocera composition. However, as only sparse fish information are available for Lake Ledro, the analysis of size structure of Daphnia spp. and Bosmina spp. was used as an indirect proxy for the reconstruction of food web changes. In fact, previous studies could related the decrease in relative abundance and in body size of Daphnia spp. and Bosmina spp. to increases in fish predation (Korosi and Smol, 2012). On the other hand, Bosmina spp. specimens with long antennules and mucro are usually recorded in conditions of high predation by invertebrates and low fish predation (Korosi and Smol, loc. cit.). Although in Lake Ledro Daphnia spp. did not show changes in the body size structure, Bosmina spp. showed a size increase of the different measured body parts since the second half of the 1980s. This alteration was linked to the presence of Bythotrephes longimanus Leydig and Leptodora kindtii (Focke), which appeared in Lake Ledro after the 1960s and reached their maximum densities in the second half of the 1980s. Changes in Cladocera body size in relation to enhanced invertebrate predation were observed also in Lake Maggiore since the 1980s (Manca et al., 2007). The secondary size shift observed during the 1930 s could not be related to the invertebrate pressure since $B$. longimanus and L. kindtii were not recorded in the sediment layer deposited in that period, in agreement with the first record of both species in the lake waters only after the 1950s (Barbato, 1977), while the correlation with other invertebrates predators could not be proved, due to the lack of such information. Nevertheless, changes in Cladocera body size are known to depend from several limnological variables, such as the TP concentrations. In fact, larger Cladocera prevail in lakes with low TP values, as they are characterized by 
lower limiting thresholds for nutrients in comparison to smaller Cladocera (Korosi et al., 2008). In Lake Ledro the secondary increase in Cladocera body size might be related to lower nutrient concentrations during the 1930s, as outlined by pigment- and diatom-inferred TP reconstructions.

Although Cladocera of Lake Ledro revealed a strong response to the major flood event in the early 1800 , no clear responses were recorded to minor hydrological perturbations as well as to lake-level regulations after 1929. The geochemical analysis showed continuous fluctuations of elements and ratios throughout the entire core in response to the constant influence of the large catchment area on the lake system, but they did not showed major changes after the lake regulation. The depth profile of $\mathrm{Pb}$ concentrations showed the typical trend recorded in the Alpine region and confirmed the larger scale atmospheric deposition pattern on the southern Alps (Rogora et al., 2006; Thevenon et al., 2011). The $\mathrm{Pb}$ pattern of Lake Ledro was highly comparable with that observed in Lake Garda (Milan, 2016), likely in relation to the vicinity of the two lakes. The Mn:Fe ratios were considered in order to assess the historical redox conditions, as anoxic conditions of the hypolimnion of Lake Ledro were recorded during the 1970s-1980s (Casellato, 1990). However, no major long term changes in redox conditions were observed, possibly as seasonal oxygen depletion at sediment-water interface represent a constant feature of this lake (Boscaini et al., 2012).

$\mathrm{Si}$ Al ratios were calculated in order to infer biogenic silica, which in turn are considered as a proxy of totaldiatom production (Peinerud et al., 2001). The Si:Al profile is highly comparable with the temporal variability of large colonial pennate diatoms along the core $(\mathrm{r}=0.75$, $\mathrm{P}<0.001$; Milan, 2016). In contrast, $\mathrm{Si}: \mathrm{Al}$ ratios and the total diatom concentrations presented comparable trends only after the $1960 \mathrm{~s}(\mathrm{r}=0.62, \mathrm{P}<0.001$; Milan, 2016), which might be explained by the different silicization degree of different diatom taxa (Peinerud et al., 2001). The $\mathrm{P}:$ Ti ratios agreed with the nutrients increase after the 1960s suggested by the TP reconstruction, while the peak in P:Ti ratio at the beginning of the 2000s agree with the increase in lake productivity indicated by the high diatom concentrations and subfossil pigments concentrations (Milan, 2016).

The proxy for changes in sediment grain size, i.e. $\mathrm{Zr}$ :Ti ratios, recorded continuous fluctuations since the 1940 s, possibly in relation to the lake-level regulation started in 1929. The $\mathrm{Rb}$ depth profile showed a comparable trend respect to $\mathrm{Zr}$ :Ti ratios, and changes in $\mathrm{Rb}$ content could be related to the lake-level regulation during the hydroelectric activity as observed in the study on Lake Majeur (Simonneau et al., 2013a). On the other hand the
$\mathrm{K}$ :AL ratios, which is a proxy of the mineral matter quality, registered only some changes during the flood events, while no significant changes were recorded after the 1940s. The XRF analyses on the sediment core of Lake Ledro were able to track secular changes in geochemical elements and outlined also a certain influence of lakelevel regulations on the sediment properties.

\section{CONCLUSIONS}

Studies of sediment Cladocera remains are still scattered for subalpine lakes. Sediments of Lake Ledro were more intensively studied for hydrological purposes than for ecological reconstructions, in relation to its peculiar morphological and hydrological features. The present paleolimnological study aimed at providing a general overview of long term effects of climatic, anthropogenic and hydrological impacts on environment and ecology of Lake Ledro, a small subalpine lake characterized by a large catchment area. Subfossil Cladocera of Lake Ledro confirmed the information on ecological preferences of several species, which were previously identified in lakes located in different European regions and the large and deep Lake Garda. Cladocera of Lake Ledro revealed a good capability in tracking major climate related changes, such as major increases or decrease in water temperature, as during the Little Ice Age, and major events of hydrological variability (i.e. floods). The development of new habitats during and after major floods in relation to higher inputs of material from the lake catchment resulted in clear changes in Cladocera species assemblages and diversity. In addition, the drastic changes in species composition, together with the increase in dominance of planktonic taxa after the 1960 s, confirmed the effects of nutrient enrichment on cladoceran communities observed in the majority of the Alpine lakes. Similarly to what observed in Lake Garda, the response of subfossil Cladocera of Lake Ledro to water temperature was stronger during periods of low lake nutrient levels, while response to nutrients prevailed in nutrient enriched stages.

The preliminary study of changes in Cladocera body size suggested the key role of invertebrate predators in affecting Bosminidae. This corroborated the usefulness of such analysis in tracking food web changes when information on fish population is not available.

The analyses of subfossil Cladocera and geochemical proxies allowed to outline a weak role of lake level regulation in affecting lake habitat and ecology. Nevertheless, this work outlined thatthe combined analysis of biological and geochemical sediment proxies is able to track the role hydrological variability in affecting environmental and ecological lake conditions. 


\section{ACKNOWLEDGMENTS}

The authors thank Adriano Boscaini, Flavia Brescancin (E. Mach Foundation - Istituto Agrario di S. Michele all'Adige) and Johan Rydberg (Umeå University) for support in the field and in the laboratory. Krystyna Szeroczyńska, Joanna Stańczak and Elżbieta Kowalczyk (Institute of Geological Sciences, Polish Academy of Sciences in Warsaw) for their support in laboratory and with Cladocera identification. The authors are grateful to Andrea Lami (ISE - National Research Council) and to Handong Yang (ENSIS Ltd. - University College of London-UK) for pigment and radiometric analyses, respectively. Authors thanks Rosalie Bruel and a second anonymous reviewer for their constructive comments. The first author thanks the International Research School in Applied Ecology (IRSAE) for the cofounding.

\section{REFERENCES}

Alefs J, Müller J, 1999. Differences in the eutrophication dynamics of Ammersee and Starnberger See (Southern Germany), reflected by the diatom succession in varve-dated sediments. J. Paleolimnol. 21:395-407.

Appleby PG, 2001. Basin analysis, coring, and chronological techniques, pp. 171-203. In: W.M. Last and J.P. Smol (eds.), Tracking environmental change using lake sediments. Kluwer, Dordrecht.

Barbato G, 1977. Note idrobiologiche sul Lago di Ledro. Ann. Mus. Civ. St. Nat. 14:92-109.

Battarbee RW, 2000. Palaeolimnological approaches to climate change, with special regard to the biological record. Quaternary Sci. Rev. 19:107-124.

Bennett KD, 1996. Determination of the number of zones in a biostratigraphical sequence. New Phytol. 132:155-170.

Bennion H, Davidson TA, Sayer CD, Simpson G, Rose NL, Sadler JO, 2015. Harnessing the potential of the multi-indicator palaeolimnological approach: an assessment of the nature and causes of ecological changes in a eutrophic shallow lake. Freshwater Biol. 60:423-1442.

Bennion H, Juggins S, Anderson NJ, 1996. Predicting epilimnetic phosphorus concentrations using an improved diatombased transfer function and its application to lake eutrophication management. Environ. Sci. Technol. 30:2004-2007.

Berthon V, Marchetto A, Rimet F, Dormia E, Jenny JP, Pignol C, Perga ME, 2013. Trophic history of French sub-alpine lakes over the last $\sim 150$ years: phosphorus reconstruction and assessment of taphonomic biases. J. Limnol. 72:417-429.

Boscaini A, Brescancin F, Salmaso N, 2012. [Progetto di ricerca per lo studio dei fattori chimico-fisici che regolano lo sviluppo del ciano batterio Planktothrix rubescens nel Lago di Ledro].[Report in Italian]. E. Mach Foundation, S. Michele all'Adige: $67 \mathrm{pp}$.
Boyle JF, 2000. Rapid elemental analysis of sediment samples by isotope source XRF. J. Paleolimnol. 23:213-221.

Boucherle MM, Züllig H, 1983. Cladoceran remains as evidence of change in trophic state in three Swiss lakes. Hydrobiologia 103:141-146.

Casellato S, 1990. [Il Lago di Ledro, valutazione del suo stato trofico].[Report in Italian]. Provincia Autonoma di Trento: $111 \mathrm{pp}$.

Davidson TA, Sayer C, Perrow M, Bramm M, Jeppesen E, 2007. Are the controls of species composition similar for contemporary and sub-fossil cladoceran assemblages? A study of 39 shallow lakes of contrasting trophic status. J. Paleolimnol. 38:117-134.

De Jong R, Kamenik C, Grosjean M, 2013. Cold-season temperatures in the European Alps during the past millennium: variability, seasonality and recent trends. Quaternary Sci. Rev. 82:1-12.

Eggermont, H, Martens K, 2011. Preface: Cladocera crustaceans: sentinels of environmental change. Hydrobiologia 676:1-7.

Finney BP, Gregory-Eaves I, Sweetman J, Douglas MS, Smol JP, 2000. Impacts of climatic change and fishing on Pacific salmon abundance over the past 300 years. Science 290:795799.

Flössner D, 2000. [Die Haplopoda und Cladocera (ohne Bosminidae) Mitteleuropas].[Book in German]. Backhuys: 428 pp.

Frey D, 1986. Cladocera analysis, p. 677-692. In: B.E. Berglund (ed.), Handbook of Holocene palaeoecology and plaeohydrology. Citeseer

Garcia-Ruiz JM, 2010. The effects of land uses on soil erosion in Spain: A review. Catena 81:1-11.

Guilizzoni P, Marchetto A, Lami A, Gerli S, Musazzi S, 2011. Use of sedimentary pigments to infer past phosphorus concentration in lakes. J. Paleolimnol. 45: 433-445.

Guilizzoni, P, Lami A, Manca M, Musazzi S, Marchetto A, 2006. Palaeoenvironmental changes inferred from biological remains in short lake sediment cores from the Central Alps and Dolomites. Hydrobiologia 562:167-191.

Hammer Ø, Harper DAT, Ryan PD, 2001. PAST-Paleontological Statistics software package for education and data analysis. Palaeontol. Electronica 4:9.

Harmsworth RV, 1968. The developmental history of Blelham Tarn (England) as shown by animal microfossils, with special reference to the Cladocera. Ecol. Monogr. 38:223-241.

HISTALP, 2013. Long series subset. Available from: http://www.zamg.ac.at/histalp/content/view/35/1/index.html

Hofmann W, 1998. The response of Bosmina (Eubosmina) to eutrophication of Upper Lake Constance: the subfossil record, p. 275-283. In: E. Bäuerle and U. Gaedke (eds.), Lake Constance: characterization of an ecosystem in transition. E. Schweizerbart'sche Verlagsbuchhandlung.

Jeppesen E, Leavitt P, De Meester L, Jensen JP, 2001. Functional ecology and palaeolimnology: using cladoceran remains to reconstruct anthropogenic impact. Trends Ecol. Evol. 16:191-198.

Jeziorski A, Yan ND, Paterson AM, DeSellas AM, Turner MA, Jeffries DS, Keller B, Weeber RC, McNicol DK, Palmer ME, 2008. The widespread threat of calcium decline in fresh waters. Science 322:1374-1377. 
Juggins S, 2007. C2 version 1.5 user guide. Software for Ecological and Palaeoecological Data Analysis and Visualisation. Newcastle University, Newcastle Upon Tyne, UK 73.

Kamenik C, Szeroczyńska K, Schmidt R, 2007. Relationships among recent Alpine Cladocera remains and their environment: implications for climate-change studies. Hydrobiologia 594:33-46.

Kauppila T, Salonen VP, 1997. The effect of Holocene treeline fluctuations on the sediment chemistry of Lake Kilpisjarvi, Finland. J. Paleolimnol. 18:145-163.

Korhola A, 1990. Paleolimnology and hydroseral development of the Kotasuo Bog, Southern Finland, with special reference to the Cladocera. Suomalainentiedeakatemia.

Korhola A, Tikkanen M, Weckström J, 2005. Quantification of Holocene lake-level changes in Finnish Lapland using a cladocera-lake depth transfer model. J. Paleolimnol. 34:175190.

Korosi JB, Kurek J, Smol JP, 2013. A review on utilizing Bosmina size structure archived in lake sediments to infer historic shifts in predation regimes. J. Pl. Res. 35:444-460.

Korosi, JB, Paterson AM, DeSellas AM, 2008. Linking mean body size of pelagic Cladocera to environmental variables in Precambrian Shield lakes: a paleolimnological approach. J. Limnol. 67:22-34.

Korosi, JB, Paterson AM, DeSellas AM, Smol JP, 2010. A comparison of pre-industrial and present-day changes in Bosmina and Daphnia size structure from soft-water Ontario lakes. Can. J. Fish. Aquat. Sci. 67:754-762.

Korosi, JB, Smol JP, 2012. Examining the effects of climate change, acidic deposition, and copper sulphate poisoning on long-term changes in cladoceran assemblages. Aquat. sci. 74:781-792.

Kruskal JB, Wish M, 1978. Multidimensional scaling. Sage Publ., Beverly Hills: 93 pp.

Kruskal WH, Wallis WA, 1952. Use of ranks in one-criterion variance analysis. J. Am. Stat. Assoc. 47: 583-621.

Kurek J, Korosi JB, Jeziorski A, Smol JP, 2010. Establishing reliable minimum count sizes for cladoceran subfossils sampled from lake sediments. J. Paleolimnol. 44:603-612.

Legendre PL, Legendre L, 1998. Numerical ecology. 2nd ed. Elsevier: 300 pp.

Lotter A, Juggins S, 1991. POLPROF, TRAN and ZONE: programs for plotting, editing and zoning pollen and diatom data. INQUA Subcommission for the study of the Holocene Working Group on Data-Handling Methods. Newsletter 6:4-6.

Magny M, Joannin S, Galop D, Vannière B, Haas JN, Bassetti M, Bellintani P, Scandolari R, Desmet M, 201. Holocene palaeohydrological changes in the northern Mediterranean borderlands as reflected by the lake-level record of Lake Ledro, northeastern Italy. Quaternary Res. 77:382-396.

Malguzzi P, Grossi G, Buzzi A, Ranzi R, Buizza R, 2006. The 1966 "century" flood in Italy: A meteorological and hydrological revisitation. J. Geoph. Res. 111:D24.

Manca M, Torretta B, Comoli P, Amsinck SL, Jeppesen E, 2007. Major changes in trophic dynamics in large, deep sub-alpine Lake Maggiore from 1940s to 2002: a high resolution comparative palaeo-neolimnological study. Freshwater Biol. 52:2256-2269.

Marchetto A, Lami A, Musazzi S, Massaferro J, Langone L, Guilizzoni P, 2004. Lake Maggiore (N. Italy) trophic history: fossil diatom, plant pigments, and chironomids, and comparison with long-term limnological data. Quatern. Int. 113:97-110.

Margaritora F, 1983. [Cladoceri (Crustacea: Cladocera) Guide per il riconoscimento delle specie animali delle acque interne italiane].[Report in Italian]. Consiglio Nazionale Delle Ricerche, Rome.

Martin-Puertas C, Jimenez-Espejo F, Martinez-Ruiz F, NietoMoreno V, Rodrigo M, Mata MP, Valero-Garces BL, 2010. Late Holocene climate variability in the southwestern Mediterranean region: an integrated marine and terrestrial geochemical approach. Clim. Past 6:807-816.

Milan M, 2016. Long-term development of subalpine lakes: effects of nutrients, climate and hydrological variability as assessed by biological and geochemical sediment proxies. Ph.D. Thesis, Umeå University.

Milan M, Bigler C, Salmaso N, Guella G, Tolotti, 2015. Multiproxy reconstruction of a large and deep subalpine lake's ecological history since the Middle Ages. J. Great Lakes Res. 41:982-994.

Nevalainen L, 2012. Distribution of benthic microcrustaceans along a water depth gradient in an Austrian Alpine lake-Sedimentary evidence for niche separation. Limnologica 42:65-71.

Oksanen J, Blanchet FG, Friendly M, Kindt R, Legendre P, McGlinn D, Minchin PR, O'Hara RB, Simpson GL, Solymos P, Stevens MHH, Szoecs E, Wagner H. 2016. Package 'vegan'. Community ecology package, version: 2.4.1.

Peinerud EK, Ingri J, Ponter C, 2001. Non-detrital Si concentrations as an estimate of diatom concentrations in lake sediments and suspended material. Chem. Geol. 177:229-239.

Perga ME, Frossard V, Jenny JP, Alric B, Arnaud F, Berthon V, Black JL, Domaizon I, Giguet-Covex C, Kirkham A, Magny M, Manca M, Marchetto A, Millet L, Paillès C, Pignol C, Poulenard J, Reyss JL, Rimet F, Sabatim P, 2015. High-resolution paleolimnology opens new management perspectives for lakes adaptation to climate warming. Front. Ecol. Evol. 3:1-17.

R Core Team, 2016. R: A language and environment for statistical computing. R Foundation for Statistical Computing, Vienna, Austria. URL https://www.R-project.org/

Rogora M, Mosello R, Arisci S, Brizzio M, Barbieri A, Balestrini R, Waldner P, Schmitt M, Stahli M, Thimonier A, Kalina M, Puxbaum H, Nickus U, Ulrich E, Probst A, 2006. An overview of atmospheric deposition chemistry over the Alps: Present status and long-term trends. Hydrobiologia 562:17-40.

Rosén P, Vogel H, Cunningham L, Reuss N, Conley DJ, Persson $P, 2010$. Fourier transform infrared spectroscopy, a new method for rapid determination of total organic and inorganic carbon and biogenic silica concentration in lake sediments. J. Paleolimnol. 43:247-259.

Rydberg J, 2014. Wavelength dispersive X-ray fluorescence spectroscopy as a fast, non-destructive and cost-effective analytical method for determining the geochemical composition of small loose-powder sediment samples. J. Paleolimnol. 52:265-276.

Sarmaja-Korjonen K, 2001. Correlation of fluctuations in cladoceran planktonic: littoral ratio between three cores from a small lake in southern Finland: Holocene water-level changes. Holocene 11:53-63. 
Shannon CE, Weaver W, 1949. The mathematical theory of communication. University of Illinois Press: $144 \mathrm{pp}$.

Simonneau A, Chapron E, Courp T, Tachikawa K, Le Roux G, Baron S, Galop D, Garcia M, Di Giovanni C, MotellicaHeino M, Mazier F, Foucher A, Houet T, Desmet M, Bard E, 2013a. Recent climatic and anthropogenic imprints on lacustrine systems in the Pyrenean Mountains inferred from minerogenic and organic clastic supply (Vicdessos valley, Pyrenees, France). Holocene 23:1764-1777.

Simonneau A, Chapron E, Vannière B, Wirth SB, Gilli A, Di Giovanni C, Anselmetti FS, Desmet M, Magny M, 2013b. Mass-movement and flood-induced deposits in Lake Ledro, southern Alps, Italy: implications for Holocene palaeohydrology and natural hazards. Clim. Past. 9:825-840.

Szeroczyńska K, 1998. Palaeolimnological investigations in Poland based on Cladocera (Crustacea). Palaeogeogr. Palaeoclimatol. Palaeoecol. 140:335-345.

Szeroczyńska K, Sarmaja-Korjonen K, 2007. Atlas of subfossil Cladocera from central and northern Europe. Friends of the lower Vistula Society: 84 pp.

Szeroczyńska K, 2006. The significance of subfossil Cladocera in stratigraphy of Late Glacial and Holocene. Studia Qua- ternaria 23:37-45.

Thevenon F, Guedron S, Chiaradia M, Loizeau JL, Pote J, 2011. (Pre-) historic changes in natural and anthropogenic heavy metals deposition inferred from two contrasting Swiss Alpine lakes. Quat. Sci. Rev. 30:224-233.

Tolotti M, Thies H, Nickus U, Psenner R, 2012. Temperature modulated effects of nutrients on phytoplankton changes in a mountain lake. Hydrobiologia 698:61-75.

Vannière B, Magny M, Joannin S, Simonneau A, Wirth SB, Hamann Y, Chapron E, Gilli A, Desmet M, Anselmetti FS, 2013. Orbital changes, variation in solar activity and increate anthropogenic activities: controls on the Holocene flood frequency in the Lake Ledro area, Northern Italy. Clim. Past. 9: 1193-1209.

Wessels M, Mohaupt K, Kümmerlin R, Lenhard A, 1999. Reconstructing past eutrophication trends from diatoms and biogenic silica in the sediment and the pelagic zone of Lake Constance, Germany. J. Paleolimnol. 21:171-192.

Wunsam S, Schmidt R, Klee R, 1995. Cyclotella-taxa (Bacillariophyceae) in lakes of the Alpine region and their relationship to environmental variables. Aquat. Sci. 57:1015-1621. 